\title{
职业教育校企文化融合研究综述
}

雷瑶 麦诗雅

广州白云工商技师学院

DOI:10.32629/er.v2i1.1593

[摘 要] 校企合作英文名为 “School enterprise cooperation”, 主要是指学校与企业建立的一种合作模式,此种模式下,职业学校 有针对性的为企业培养人才, 注重人才的实用性与实效性,提高职业学校学生的就业率,是职业学校谋求自身发展,抓好教育质 量的重要途径。基于此,本文就展开职业教育校企文化融合方法的研究工作,以期为职业教育提供参考依据。

[关键词] 职业教育; 校企文化; 融合方法; 研究综述

进入二十一世纪后, 我国社会经济发展迅猛, 国家产业 技术升级速度不断加快, 使得社会上对高技能人才的需求量 逐渐增加。在 2017 年 10 月 18 日中国共产党第十九次全国 代表大会上, 习近平总书记明确指出, 需要优先发展教育事 业, 为社会主义培养德智体美全面发展接班人。因此, 高职院 校需要积极展开校企合作, 让在校学习与企业实践同步进行, 提高学生学习效果。

\section{1 职业教育校企文化融合的重要意义阐述}

众所周知, 校企合作符合职业教育发展的内在规律, 有 利于促进职业教育发展; 有利于企业实施人才战略; 有利于 学生提高就业竞争力, 解决学生就业困难的问题, 可见, 意义 重大, 具体如下:

\section{1 职业教育校企文化融合有利于提高学生综合素质}

高职院校有属于自己的办学目的, 与普通大学院校不同, 高职院校更加注重学生技能培养 ${ }^{[1]}$ 。在传统的教育模式下, 职 业教育内容单一, 多集中在理论知识上, 缺少学生实践教育, 导致学生对所学习到的知识不会应用, 难以实现教学目标。而 职业教育校企文化融合刚好可以解决此种问题, 高职院校将 企业文化融入到教育教学管理中, 有针对性的设置教育内容、 管理方法, 然后企业为学生提供实践训练基地, 让学生可以动 手操作, 深入到企业了解技能, 从而提高每一位学生的学习热 情, 激发学生学习潜能, 提高学生综合素质。

1.2 职业教育校企文化融合有利于校企合作的深入发展 ${ }^{[2]}$ 现阶段, 高职院校的办学宗旨为 “立足行业、服务企业” ${ }^{[3]}$, 力求为企业培养更多的技术型人才, 并提高院校自身的核心竞 争力。在此种情况下, 职业教育校企文化融合的展开, 可以让高 职院校文化和企业文化快速融合, 然后制定出全方位的学生 综合职业素养培养对策, 让职业院校和企业之间的合作做到 由浅入深、由外向内、由物质向精神的转变, 从而为校企合 作的深入发展奠定基础, 起到促进作用。

1.3 职业教育校企文化融合有利于形成职业院校文化

众所周知, 每一个学校都有属于自己的文化, 高职院校 也不例外, 在职业教育校企文化融合的培养下, 可以帮助高 职院校形成属于自己的职业院校文化, 具体主要体现在以下 两个方面: 一方面, 职业教育校企文化融合可以让职业院校
创建具有职业特色的院校文化和品牌, 并形成校园内部文化 特色, 加强教育体系建设, 为高职院校今后发展奠定基础。另 一方面, 职业教育校企文化融合可以提升高职院校的文化软 实力, 让高职院校的办学水平、办学实力等内容都得到提升, 从而可以弥补校园文化建设的不足, 推动高职院校快速发展。

1.4 职业教育校企文化融合有利于节约企业经营成本 ${ }^{[4]}$

现阶段, 在我国社会经济发展迅速的背景下, 各个学校 发展脚步不断加快, 使得每一年所需要支出的成本非常高。 而职业教育校企文化融合刚好可以解决此种情况, 帮助企业 解决经营成本, 具体体现在以下两个方面: 一方面, 通过职业 教育校企文化融合, 可以让企业更加全方位的了解学生, 对 学生进行近距离的观察与评价, 合理选择所需人才, 降低人 才挖掘成本。另一方面, 通过职业教育校企文化融合, 可以让 高职院校学生就业率得到保证, 企业为学生提供大量工作岗 位, 学生毕业后, 可以直接上岗工作, 在此种情况下, 可以有 效节省企业对新员工的培训费用, 从而节约企业经营成本, 推动企业快速发展。

1.5 职业教育校企文化融合有利于企业文化的可持续发展

众多周知, 企业在发展过程中, 企业文化是灵魂, 如果企 业缺少为企业文化, 那么各种工作、活动的展开效率就会直线 下降, 不利于企业长久、稳定的发展。而职业教育校企文化刚 好可以解决此种情况, 通过校企文化融合, 将学校文化的人文 性、学术性、科学性、包容性、批判性等特点融入到企业文 化中, 重新塑造企业文化, 丰富企业文化内涵, 从而让企业朝 向学习型组织发展, 不断提高自身文化品位, 站稳市场。

1.6 职业教育校企文化融合有利于企业获取人才

人才是企业发展的必要条件之一, 如果企业中缺少人才, 那么其发展就会受到限制, 难以朝向预期目标前进。针对此 种情况, 高职院校就需要积极展开职业教育校企文化融合工 作, 在高职院校学生教育工作中融入企业的团队意识、协作 意识、竞争意识等等。与此同时, 高职院校需要根据企业需 求合理设置教学内容、教学专业以及教学方案, 充分做好专 业建设与岗位发展的衔接工作, 确保能够为企业培养更多优 秀的专业型人才, 从而有利于企业获取人才, 为企业实现可 持续发展奠定基础。 


\section{2 职业教育校企文化融合的主要模式分析}

现阶段, 高职院校在展开职业教育过程中, 主要强调 “个 性化” 培养, 而企业主要强调 “团队合作” 培养, 两者有着一 定区别。针对此种情况, 高职院校在进行职业教育校企文化 融合时, 就需要合理选择融合模式, 具体可以从以下几个方 面展开。

2.1 职业教育校企文化融合采用 “订单培养模式” [5]

订单培养模式又可以称之为 “人才定制”, 主要是指高职 院校针对企业所需人才数量、岗位等内容, 从精神层面、角色 层面、实训层面、管理层面等层面出发合理展开学生培训工 作, 此种培养模式具有多种优点, 如, 就业稳定性高、学生就 业适应期短等等, 因此, 可以让学生更加快速的接纳企业管 理文化。

\section{2 职业教育校企文化融合采用 “四入培养模式”}

所谓 “四入培养模式”, 其中 “四入” 主要指企业文化 “入眼”、企业文化 “入脑”、现企业文化 “入心” 以及企业 文化 “入行” [6], 在此种模式下, 高职院校就需要注重校园环 境建设, 然后将课堂教学和实践教学相结合, 从而提高学生 学习效果, 让学生正确了解企业文化, 为其今后步入企业工 作打下有力基础。

2.3 职业教育校企文化融合采用 “四五四重构模式”

所谓 “四五四重构模式” 就是指四维度、五载体、四体 系” 的重构 ${ }^{[7]}$, 在此种模式下, 高职院校在展开校企文化融合 时, 就需要严格做到从精神、制度、行为、物质四个方面出 发, 然后合理分析, 针对性制定学生课程教育、实践教学方案, 确保高职院校可以顺利实现职业教育校企文化融合。

2.4 职业教育校企文化融合采用 “3S 融合模式”

$3 \mathrm{~S}$ 融合模式主要是指学校、教师、学生这三方面的校企 文化融合, 具体需要做到以下两点: 一方面, 高职院校需要加 强校园文化建设和教学创新工作, 为学生提供良好的教育资 源和学习环境。另一方面, 教师需要注重学生的培养, 可以通
过项目引领、任务驱动等多种方法, 培养学生的创新能力, 从 而让高职院校职业教育校企文化融合工作稳定有序的进行。

2.5 职业教育校企文化融合注重制度文化等方面建设工作 高职院校在展开职业教育校企文化融合时, 需要从文 化、精神、物质等多方面出发, 构建校企文化融合制度, 充分 做到优势互补、协同创新, 从而实现校企文化的深度融合。

\section{3 结束语}

在教育行业不断改革的背景下, 校企合作逐渐成为职业 教育内涵发展的必由之路, 在此种教育模式下, 注重实践与 理论的结合, 让职业教育与市场接轨, 培养更多社会上所需 要的高技能人才, 有利于实现学校与企业资源、信息共享的 “双赢”。因此, 高职院校在展开职业教育过程中, 需要大力 推进 “校企合作”, 做到在共同文化价值观基础上进行融合, 从而培养更多现代企业需要的应用型技能人才, 推动现代企 业实现可持续发展。

\section{[参考文献]}

[1]徐春梅,刘世民.基于组织文化视角的职业教育校企 文化融合研究 [J].职教论坛,2017,(2):35-43.

[2]郑长青,张玲,熊望,等.有效融合校企文化精髓锻造高 素质职业团队探究[J].消费导刊,2016,(5):229-231.

[3]孙悦.校企文化对接趋势下的高职校园文化发展现状 与分析[J].中小企业管理与科技,2014,(14):231-233.

[4]元新学.融合校企文化改革高职教育人才培养模式 [J].阜阳职业技术学院学报,2014,(2):4-6.

[5]陈一鸣.以校园文化活动为载体,加强校企文化融合 - - 桂西欠发达地区中职学生职业素养培养之道[J].都市家 教(下半月),2016,(7):78.

[6]陈颜红,杨志强.可持续发展的高职院校校企文化融通 研究综述[J].河南科技学院学报(社会科学版),2017,37(10):5-8.

[7]诸玉富.校企文化耦合背景下高职学生职业能力培养 问题研究[J].现代职业教育,2018,(12):236-237. 